University of California

Division of Agriculture and Natural Resources

http://anrcatalog.ucdavis.edu

\title{
SLUGS
}

\section{A Guide to the Invasive and Native Fauna of California}

RORY J. MC DONNELL, Department of Entomology, University of California, Riverside; TIMOTHY D. PAINE, Department of Entomology, University of California, Riverside; and MICHAEL J. GORMALlY, Applied Ecology Unit, Centre for Environmental Science, National University of Ireland, Galway, Ireland

\section{Introduction}

Slugs have long been regarded worldwide as severe pests of agricultural and horticultural production, attacking a vast array of crops (reviewed by South [1992] and Godan [1983]). Species such as Deroceras reticulatum (Müller ${ }^{1}$ ), Arion hortensis d'Audebard de Férussac, and Tandonia budapestensis (Hazay) are among the most pestiferous (South 1992) and have increased their ranges as humans have continued their colonization of the planet. Slugs have also been implicated in the transmission of many plant pathogens, such as Alternaria brassicicola Schw., the causal agent of brassica dark leaf spot (Hasan and Vago 1966). In addition, they have been implicated as vectors of Angiostrongylus cantonensis (Chen), which can cause the potentially lethal eosinophilic meningo-encephalitis in humans (Aguiar, Morera, and Pascual 1981; Lindo et al. 2004) and Angiostrongylus costaricensis Morera and Céspedes, which causes abdominal angiostrongyliasis (South 1992). Recent evidence also indicates that slugs vector Campylobacter spp. and Escherichia coli (Migula), which cause food poisoning and may have been partially responsible for recent, highly publicized massive recalls of contaminated spinach and other salad crops grown in California (Raloff 2007, Sproston et al. 2006). 
In California, slugs and humans have had a long history. The Yurok people used the native banana slug Ariolimax columbianus (Gould in A. Binney) as a food source in times of shortage. During the 1800 s and early 1900s, German immigrants also used this native species for food (Kroeber 1976). Although invasive slugs (D. reticulatum) were reported in the state as early as 1891 (Lovatt and Black 1920), until now no identification keys have existed for the invasive fauna. This is surprising, considering the obvious adverse effects that invasive species are likely to have on California's estimated \$32-billion-a-year agriculture industry (California Department of Food and Agriculture 2006).

This publication provides a field identification key to the different families, genera, and species of invasive slugs in California. Based on our collecting experience, most of the damage to agricultural and horticultural production is attributable to the invasive fauna, while native species seldom reach pest status. However, we also provide an identification key to native genera (indicated by an asterisk $\left.{ }^{*}\right]$ ) and a brief description of this fauna. A key to native species is being prepared by other authors.

Although many invasive species can be identified on the basis of external characteristics, some (e.g., Arion distinctus Mabille) can only be reliably identified through dissection and examination of genitalia. For all species, we provide diagnostic field characters in addition to details of the genitalia in the species descriptions. For problematic species (as noted in the key) in particular, dissection is recommended to confirm identification. We also provide brief descriptions of closely related species that are found throughout Europe and of invasive species that have not yet been recorded in California, but are likely to appear in the near future. We encourage collectors to be especially vigilant for Arion lusitanicus Mabille (= vulgaris Moquin-Tandon) (see Figure 20) and T. budapestensis (see Figures 21a and 21b), which are very serious agricultural pests in Europe and other parts of the world. Any observation of these species and other new discoveries should be reported to the authors and the National Malacologist (USDA APHIS PPQ NIS, Department of Malacology, Academy of Natural Sciences, 1900 Ben Franklin Parkway, Philadelphia, PA 19103, http://www.ansp.org/ research/biodiv/malacology_home.php).

\section{Collection Techniques and Behavioral Observations}

Slugs tend to be nocturnal in habit but can be collected quite easily during the day if you search under sources of cover (e.g., old pieces of wood, rocks or stones, flower pots, old sheets of plastic, and sprinkler valve box covers) in suitable habitats. Alternatively, you can use baited traps as a collection tool: cat or dog food covered with a black plastic refuse bag pinned at each corner and left overnight was used by Mc Donnell et al. (in press), for example, to successfully collect slugs in Kentucky. Another useful technique for collecting slugs is to remove a turf-soil core (e.g., $30 \mathrm{~cm} \times 30 \mathrm{~cm}$ ) and wash it with water in a sieve. This is an important collection method for slug species such as T. budapestensis and Testacella haliotidea Draparnaud, which are predominantly subterranean. Specimens can be kept alive in a small plastic container lined with a damp paper towel and fed on organic vegetables. If possible, make identifications using living specimens, as certain behavioral traits (e.g., response to a continuous disturbance) are important in identifying some species. However, preservation and dissection will be required to accurately determine some species.

\section{Guide to Slug Preservation and Dissection}

Prior to dissection, make notes on collection locality and date as well as slug size and color. Multiple photographs (dorsal, ventral, and side views) should also be taken of the specimen. The best way to kill and preserve a slug involves using a jar filled with boiled water that has been allowed to cool. Place the specimen into the jar and seal it. After 24 hours you can remove the dead slug and place it in 70\% ethanol. Slugs preserved in this manner will be extended and easier to dissect than those that have been placed directly into alcohol. However, if specimens are required for molecular studies, the tip of the tail should be excised prior to killing and placed in 100\% ethanol.

You can easily prepare a useful dissection arena by pouring hot wax into a Petri dish to a depth of about $5 \mathrm{~mm}$ and allowing it to solidify. Place the slug right-side-up onto the dish, straighten its body, and 
insert pins through the head (close to the tentacles) and close to the tip of the tail. Then add water to the dish until it covers the specimen. Now use a fine, sharp scalpel to cut along broken line $\mathrm{A}$ as shown in Figure 1. It is important that the cut be made just below the surface and that the dissection be on the right-hand side of the specimen (your right, if the slug's head is pointing away from you). The cut must also go below the genital pore, which generally is located anterior to the breathing pore. The cut flap of tissue can now be peeled back (B) to reveal the internal organs. The genitalia can be followed back from the genital pore and are usually bright white in color. Beginners may find it helpful to practice dissections on larger species such as Arion rufus L. before they progress to smaller specimens. For additional details on slug dissection techniques, see Kerney and Cameron (1979).

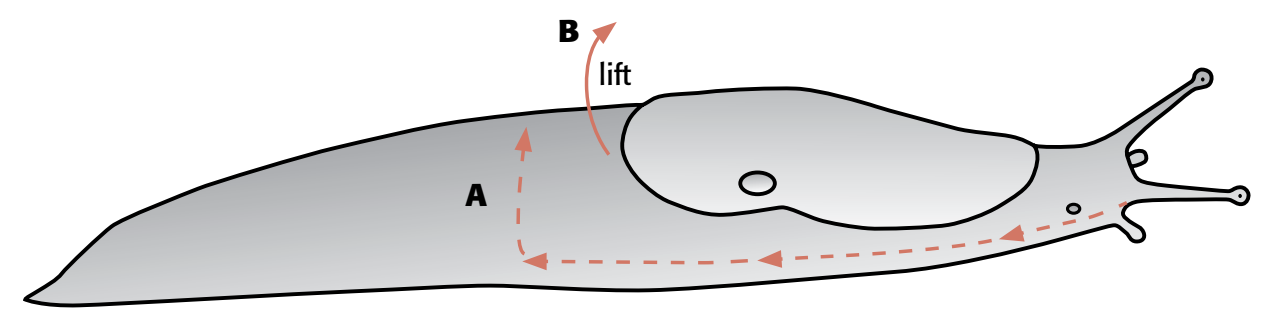

Figure 1. Recommended direction of dissection to expose slug genitalia. Make an incision close to the tentacles, cut along the broken line $(A)$ ensuring that the cut passes below the genital pore, and then lift the flap of tissue (B).

\section{Basic Slug Anatomy}

The basic external characteristics of a slug are illustrated in Figure 2. Many of these features are referenced throughout the key that follows. The tubercles-raised humps on the back of slugs that give the appearance of ridges and grooves on the bodyare omitted from this illustration to make it easier to follow. Tubercles are clearly visible in the specimen of D. reticulatum in Figure 7. The caudal mucus pore is a mucus-secreting gland found at the end of the tail in certain species of arionid slugs. In many cases it is filled with a mucus plug (e.g., A. rufus L.), but it may also be empty (e.g., Hesperarion niger Cooper).
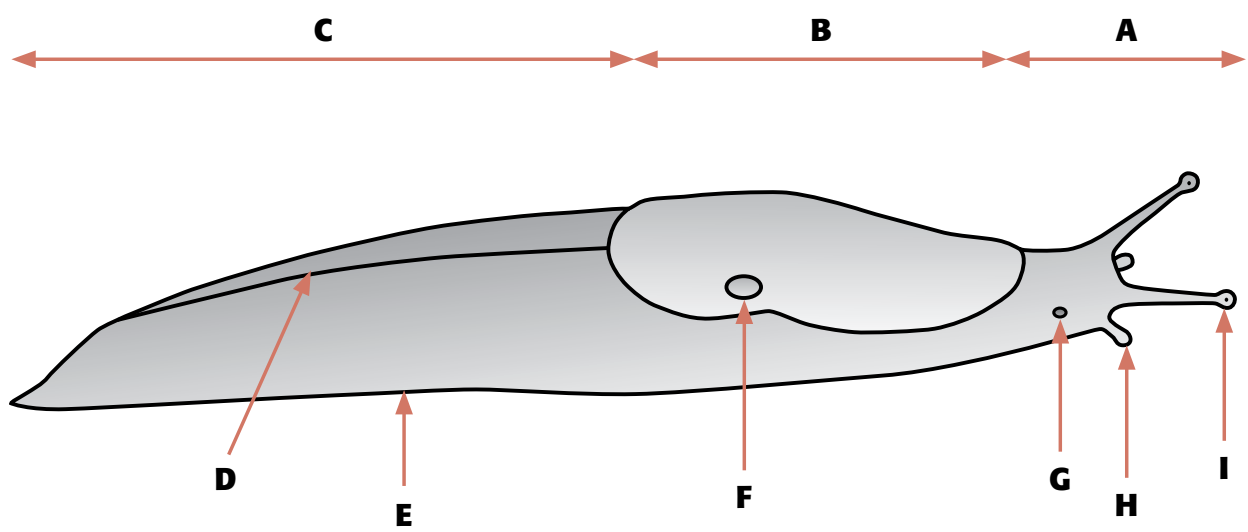

Figure 2. Basic external slug features: head (A), mantle (B), tail (C), keel (D), foot sole (E), pneumostome or breathing pore $(F)$, genital pore $(G)$, sensory tentacle $(H)$, ocular tentacle $(I)$. 
Figure 3 is a generalized illustration of slug genitalia. In order to view the atrial ligula or stimulator, which is important in identifying certain species within the families Arionidae and Milacidae, you will need to cut open the atrium (the part of the genetalia that is attached to the body wall). The ligula itself is a muscular structure that is everted during copulation. The epiphallus structure is also located within the atrium (at the outlet of the epiphallus) and it is diagnostic in distinguishing the different species of the Arion hortensis complex. The penile flagellum shown in Figure 3 is present in only certain species (e.g., Lehmannia valentiana [d'Audebard de Férussac]). Additional details on the internal anatomy of the various slug families and species can be found in Backeljau and Van Beeck (1986), Barker (1999), Forsyth (2004), Kerney and Cameron (1979), Pinceel et al. (2004), and Quick (1960).

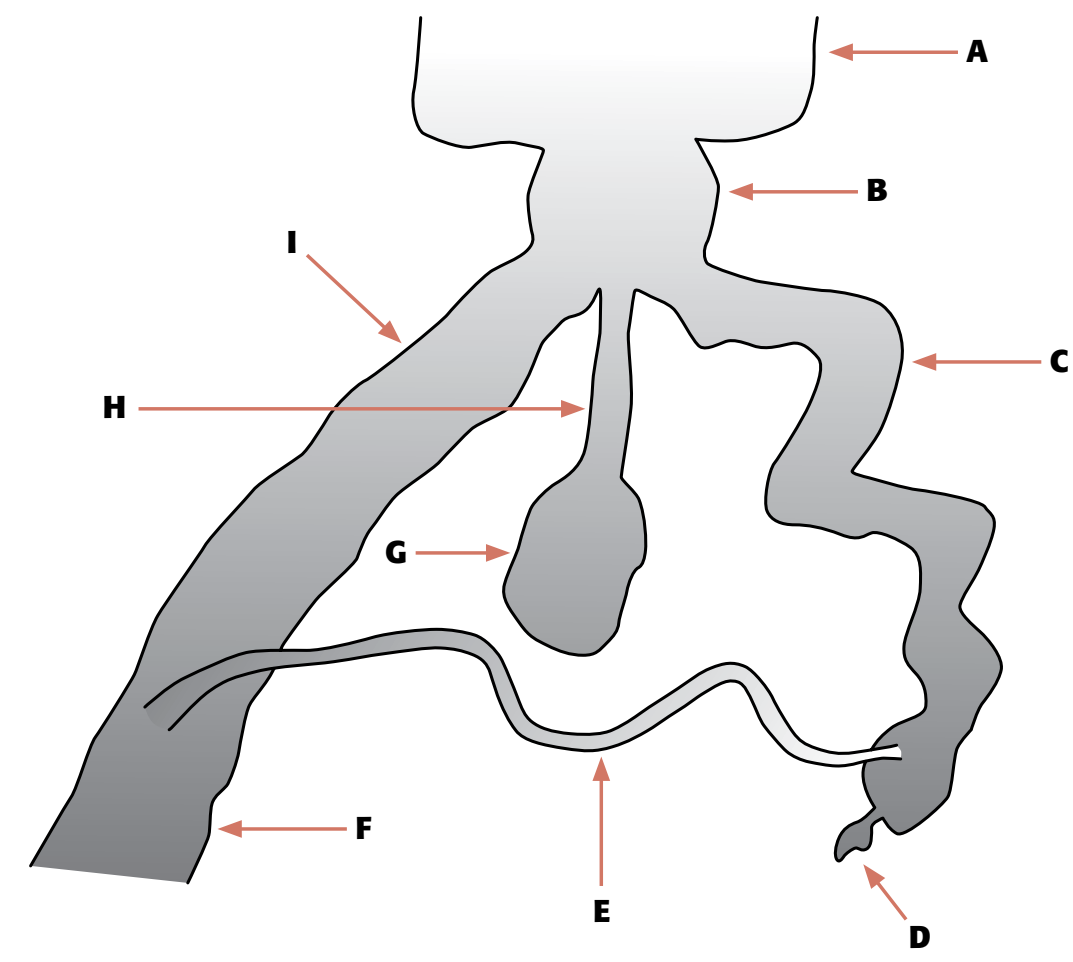

Figure 3. Generalized diagram of slug genitalia: body wall (A), atrium (B) (ligula or stimulator located inside), penis (C) (epiphallus in Arionidae), flagellum (D), vas deferens (E), conjoint or hermaphrodite duct $(F)$, spermatheca $(G)$, spermathecal duct $(H)$, oviduct $(I)$. 


\section{(A) Key to Invasive and Native Slug Families}

Genera denoted by $*$ are native to California.

1. Slug with an obvious external shell. ..... skip to 2

Slug without an external shell.......... skip to 3

2. Shell relatively large, whorled, and located at the midpoint of the body

........... Family Arionidae (Genus Binneya*)

Shell relatively small, unwhorled, and located at the posterior end of the body (Figure 4)

$\ldots \ldots \ldots \ldots \ldots$. . . Family Testacellidae

3. Mantle covers the entire length of the body; pneumostome (respiratory opening) not obvious (Figure 5)..............Family Veronicellidae

Mantle does not cover entire body; an obvious pneumostome located on the right-hand side of the mantle (Figure 6) .............skip to 4
4. Pneumostome located anterior to or at the midpoint of the mantle (Figure 6)

............. Family Arionidae (Genera Arion, Prophysaon*, and Anadenulus*)

Pneumostome located posterior to the midpoint of the mantle (Figure 7 ) ............. skip to 5

5. Caudal mucus pore present at the tip of the tail .......... Family Arionidae (Genera Ariolimax ${ }^{*}$ and Hesperarion*)

Caudal mucus pore absent . skip to 6

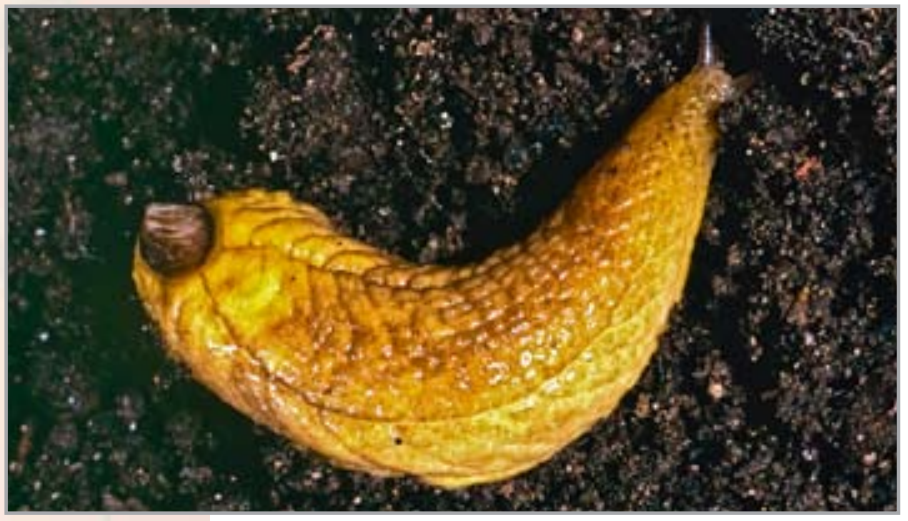

Figure 4. Testacella haliotidea Draparnaud. The external shell at the posterior end of the body is diagnostic for Family Testacellidae. Photograph by Roy Anderson.

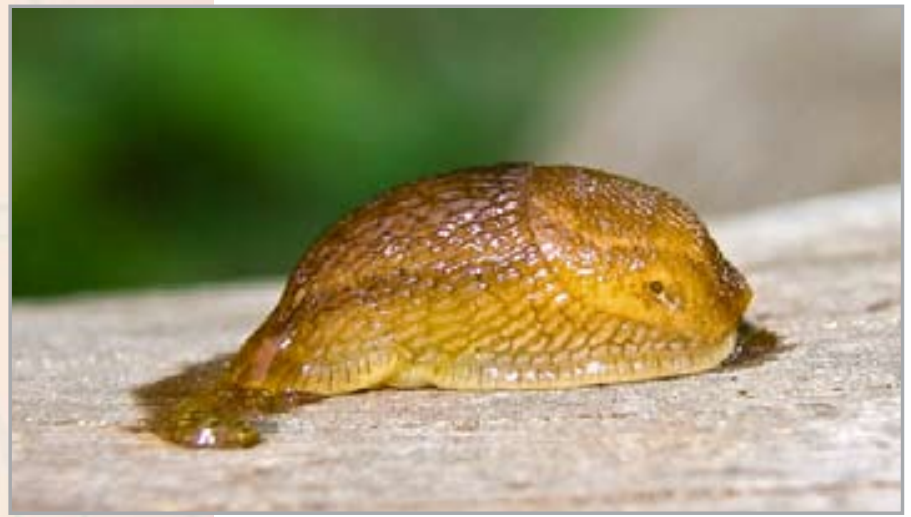

Figure 6. Arion subfuscus (Draparnaud). The location of the pneumostome anterior to the midpoint of the mantle is a diagnostic feature of Family Arionidae. Photograph by Michal Maňas.

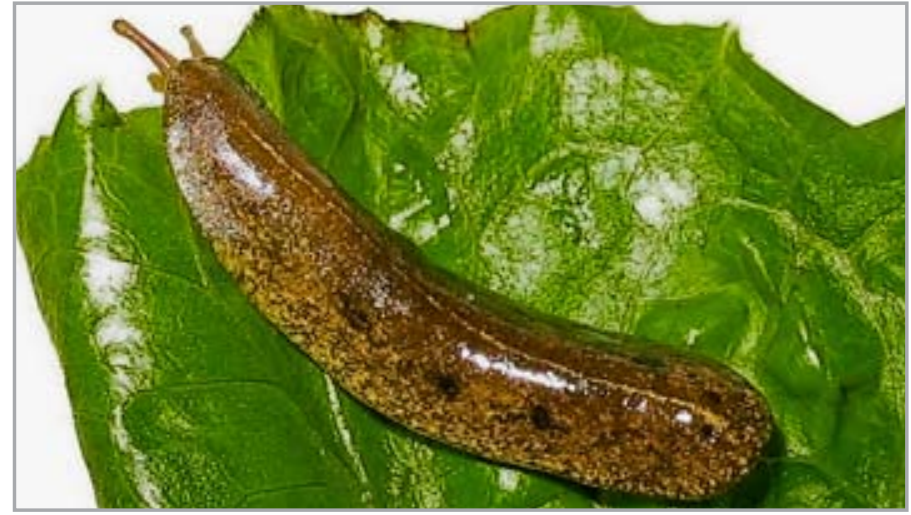

Figure 5. Veronicella cubensis (Pfeiffer). The mantle covering the full length of the body is a diagnostic characteristic of Family Veronicellidae. Photograph by Rory Mc Donnell.

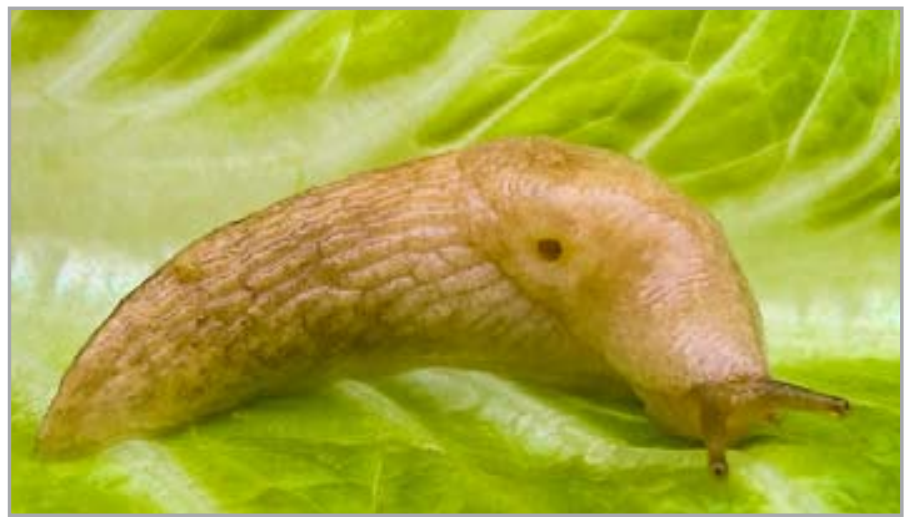

Figure 7. Deroceras reticulatum (Müller). The posterior position of the pneumostome to the midpoint of the mantle separates Families Agriolimacidae and Limacidae from Arionidae. Photograph by Rory Mc Donnell. 
6. Mantle with a horseshoe-shaped furrow; keel runs from end of mantle to tip of tail (Figures $8 \mathrm{a}$ and $8 \mathrm{~b}$ ).......... Family Milacidae

Mantle without a horseshoe-shaped groove; keel shorter than above ................skip to 7

7. Mantle ridges/wrinkles centered to the right of the mantle over the pneumostome $\ldots \ldots \ldots \ldots \ldots$. Family Agriolimacidae Nucleus of mantle ridges lies on the mid-dorsal line.................... Family Limacidae

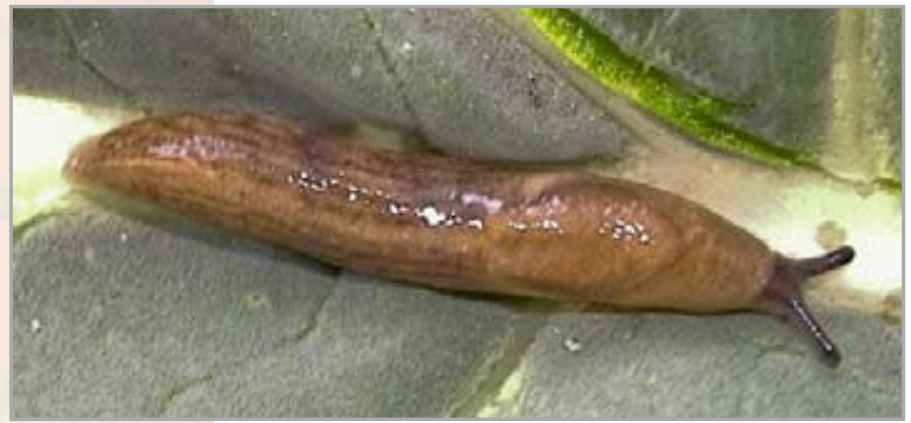

Figure 8a. Milax gagates (Draparnaud). Keel runs from end of mantle to tip of tail. Individuals of this species can also be black or dark gray. Photograph by Rory Mc Donnell.

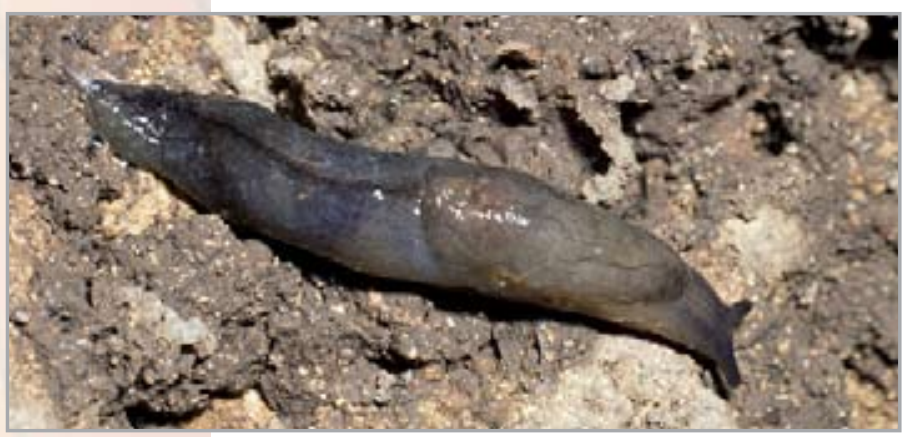

Figure 8b. Milax gagates (Draparnaud). Photo by Roy Anderson.

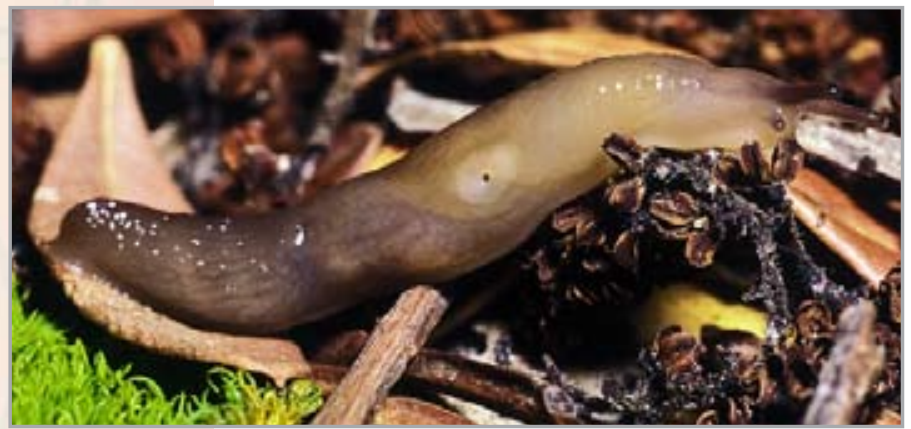

Figure 10. Deroceras panormitanum (Lessona and Pollonera). Photograph by Roy Anderson.

\section{(B) Key to Invasive Genera and Species}

\section{Family Agriolimacidae}

1. Gray oatmeal to cream color, usually reticulated; a milky-colored, very sticky mucus secreted when continuously disturbed (use an artist's paintbrush) (Figure 9)............ Deroceras reticulatum

Ground color brown; mucus colorless and watery .....................skip to 2

2. Tip of the tail rises up from the sole vertically or may curve backward; rim of pneumostome may be noticeably more pale than rest of body; sole light gray; body appears to be thin-walled, giving a translucent appearance; very aggressive species, tail-lashes when continuously disturbed (use an artist's paintbrush) (Figure 10); dissection required .... Deroceras panormitanum

Tip of the tail slopes forward; rim of pneumostome usually not conspicuously more pale than rest of body; sole light brown; body not appearing as translucent; rarely displaying aggressive tail-lashing behavior (Figure 11); dissection required

\section{Deroceras laeve}

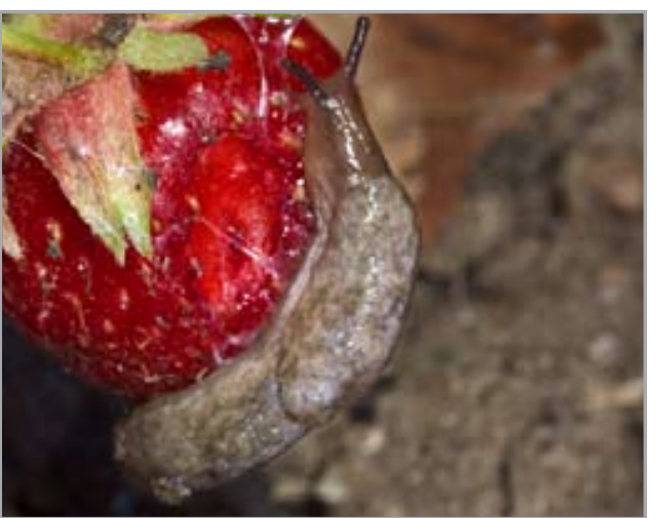

Figure 9. Deroceras reticulatum (Müller). Milky colored mucus is a diagnostic feature of the species. Photograph by Jack Kelly Clark.

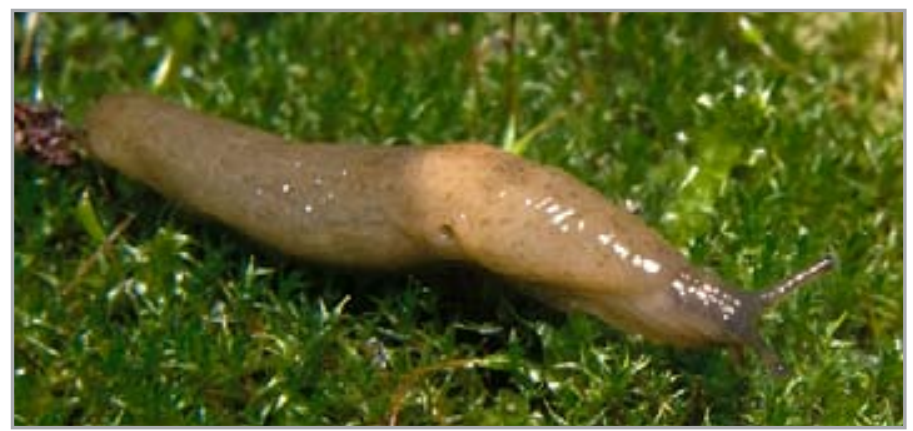

Figure 11. Deroceras laeve (Müller). Photograph by Roy Anderson. 


\section{Family Arionidae Key to genera}

1. Slug with an obvious whorled external shell ......................... Binneya ${ }^{*}$

Slug without an external shell......... skip to 2

2. Pneumostome located posterior to the midpoint of the mantle.....................skip to 3

Pneumostome located anterior to or at the midpoint of the mantle..................... skip to 4

3. Very large slug $(>50 \mathrm{~mm})$; caudal pore filled with a mucus plug . .................. Ariolimax ${ }^{*}$

Smaller slug $(<50 \mathrm{~mm})$; caudal pore deep and unfilled.................... Hesperarion*

4. Pnemostome located at the midpoint of the mantle; sole distinctly tripartite ........... Anadenulus*

Pneumostome located anterior to the midpoint of the mantle; sole not distinctly tripartite... .skip to 5

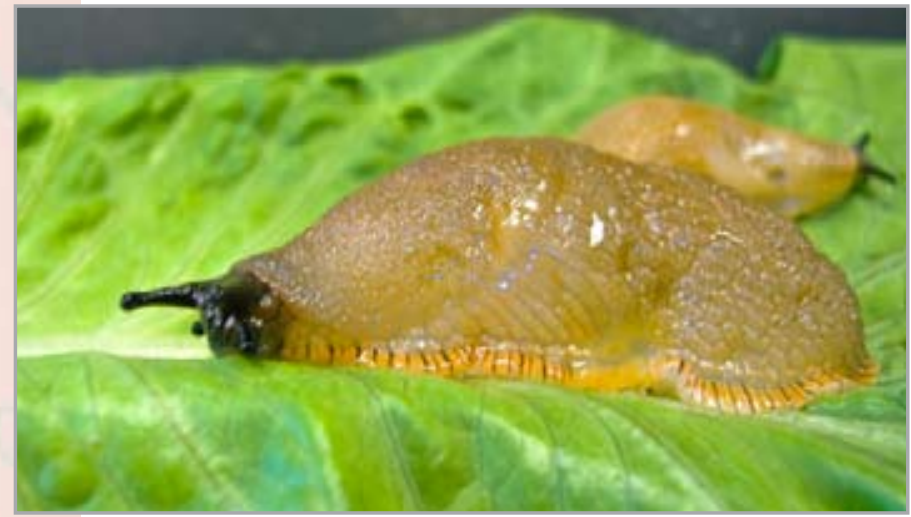

Figure 12. Arion rufus (Linnaeus). Photograph by Rory Mc Donnell.
5. Tail with an oblique constriction in posterior half (often present as a single, darkish, lateral line on the sole) ...................Prophysaon*

Tail without an obvious constriction or a dark lateral line on the sole ................... Arion

\section{Key to species of Arion}

1. Very large slug (up to $180 \mathrm{~mm}$ long); sometimes exhibits a "rocking" motion when disturbed; foot fringe orange to red with distinct lineolations and contrasting with the duller body colors; head and tentacles darker than rest of body (Figure 12); sole variable in color but usually matching upper surface; sole mucus very pale or colorless .Arion rufus

Smaller slug; does not exhibit a "rocking" motion when disturbed ...................skip to 2

2. Very small slug ( $\leq 25 \mathrm{~mm})$; has a prickly appearance (use a hand lens) when contracted or when left in cool conditions (e.g., in a refrigerator) for some time; head and tentacles darker than rest of the body (Figure 13)....... Arion intermedius

Larger slug; not prickly in appearance when contracted or at rest ................skip to 3

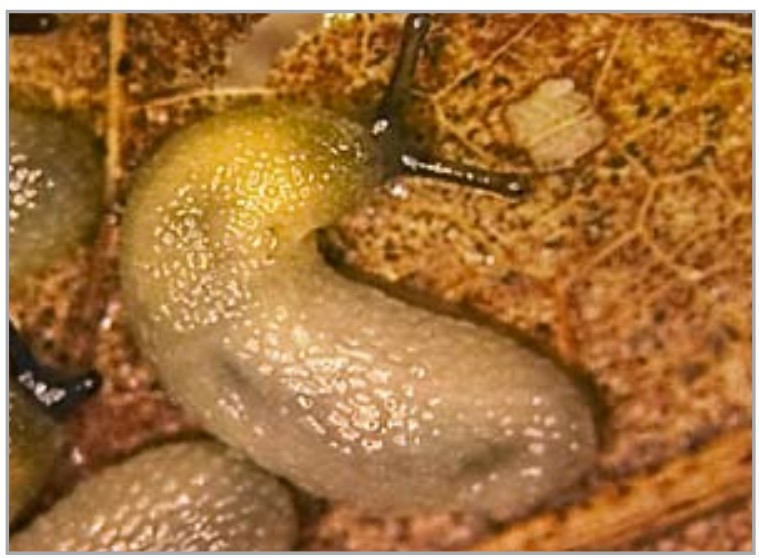

Figure 13. Arion intermedius Normand. Photograph by Rory Mc Donnell and James Harwood. 


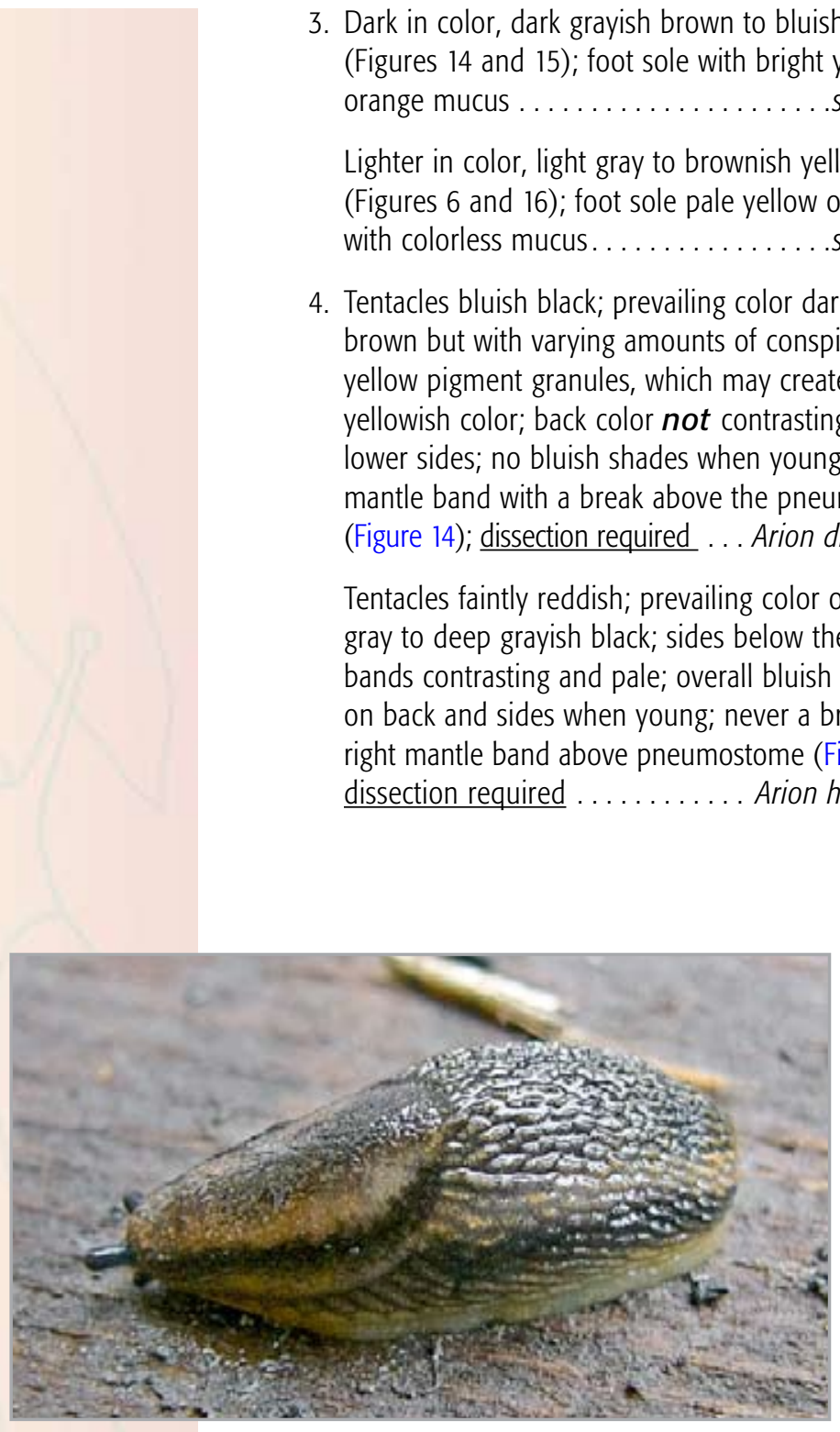

Figure 14. Arion distinctus Mabille. Photograph by Michal Maňas.

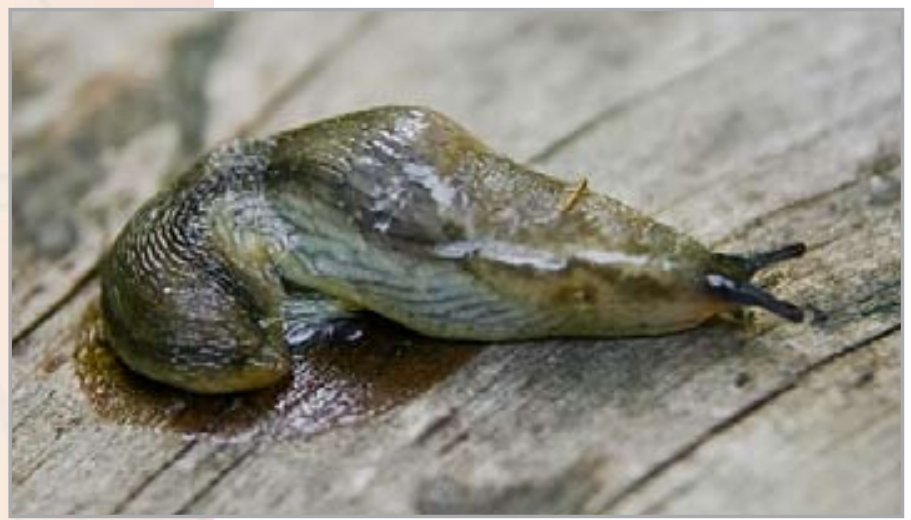

Figure 16. Arion silvaticus Lohmander. Photograph by Michal Maňas.
5. Slug does not contract into a hemispherical shape when disturbed; foot fringe with thin but distinct lineolations; body mucus orange-yellow; foot sole translucent-pale (see Figure 6) ... Arion subfuscus

Slug contracts into a hemispherical shape when disturbed; sole fringe lacks distinct lineolations; body mucus colorless; foot sole opaque white (Figure 16).............. Arion silvaticus

\section{Family Limacidae}

1. Body yellowish with green mottling/spots; tentacles contrasting petrol blue; slime copious and slippery; keel weak and rounded, only obvious near the tip of the tail but often marked by a pale line; mucus yellow (Figure 17) ............ Limacus flavus

Body without green mottling; tentacles light to dark brown; mucus colorless. ............ skip to 2

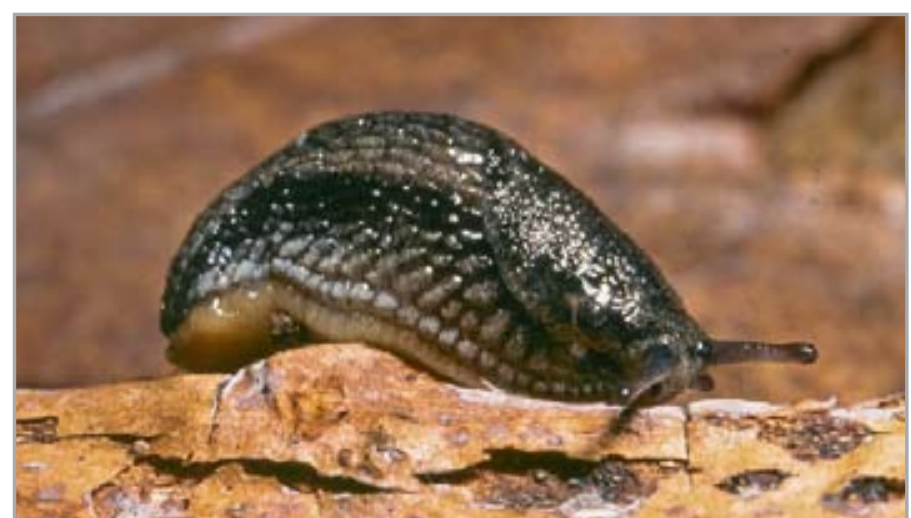

Figure 15. Arion hortensis d'Audebard de Férussac. Photograph by Roy Anderson.

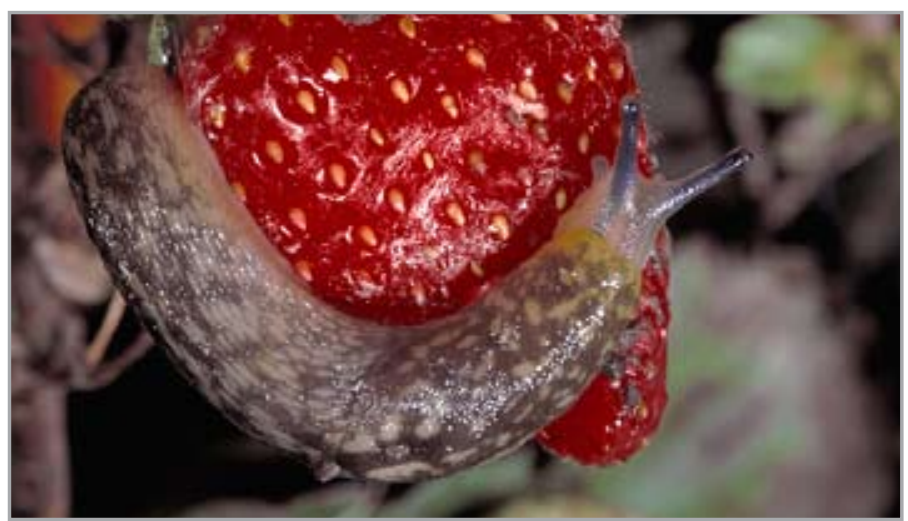

Figure 17. Limacus flavus (Linnaeus). Photo by Jack Kelly Clark. 
2. Up to $200 \mathrm{~mm}$; mantle spotted or marbled; slime sparse, sticky; keel well marked, acute; there may be lateral bands on the tail but never on the mantle (Figure 18)............... Limax maximus

Up to $75 \mathrm{~mm}$; mantle with two distinct lateral bands and a less distinct median band; slime copious, watery; keel poorly marked, rounded (as in $L$. flavus); lateral bands may run full length of the body (Figure 19) ........ Lehmannia valentiana

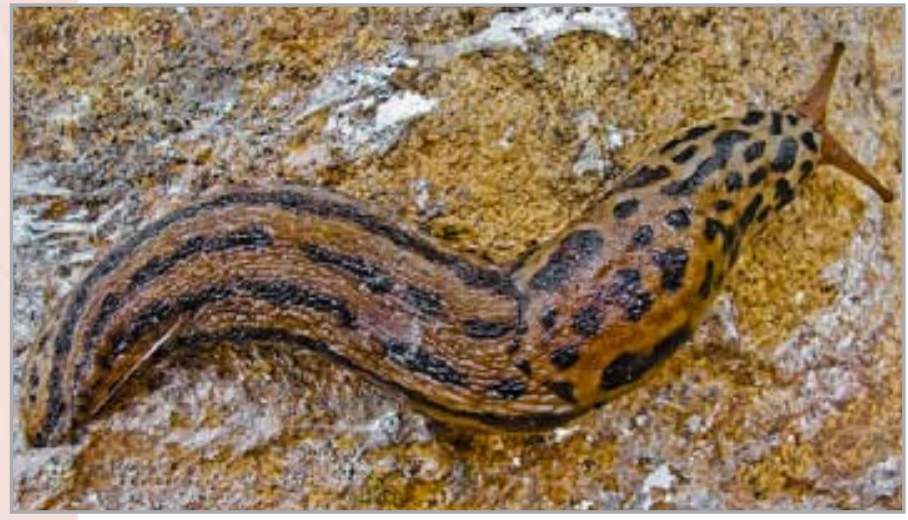

Figure 18. Limax maximus Linnaeus. Photograph by Michal Maňas.

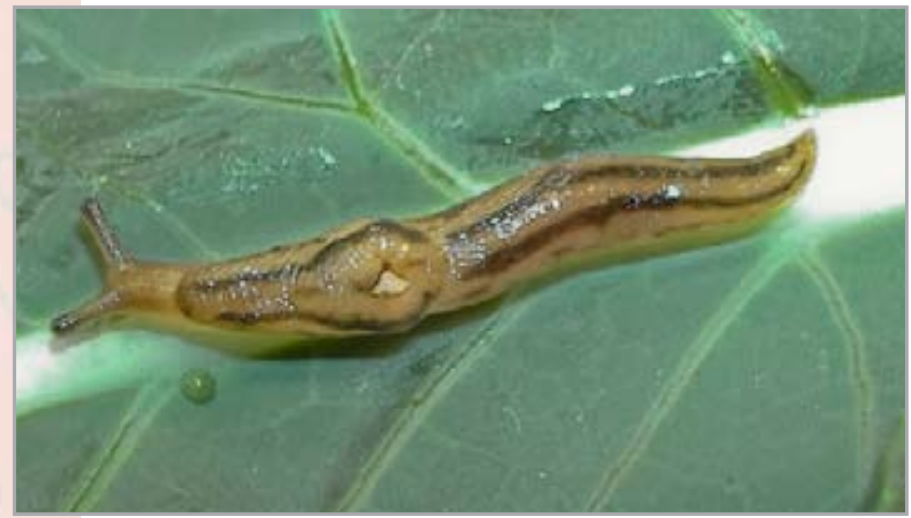

Figure 19. Lehmannia valentiana (d'Audebard de Férussac). Photograph by Rory Mc Donnell.

\section{Family Milacidae}

Only one species, Milax gagates, has been recorded in California; see Figures 8a and 8b.

\section{Family Testacellidae}

Only one species, Testacella haliotidea, is known from California; see Figure 4.

\section{Family Veronicellidae}

One species, Veronicella cubensis, has recently been recorded in California (Mc Donnell et al. 2008); see Figure 5.

\section{Species Descriptions}

\section{NATIVE SPECIES}

A total of seventeen native species in six genera are known from California. The best researched (Leonard, Pearse, and Harper 2002; Gervais, Traveset, and Wilson 1998; Harper 1988) and most well known belong to the genus Ariolimax Mörch (Banana Slugs), of which there are seven species: Ariolimax buttoni (Pilsbry and Vanatta), A. californicus californicus Cooper, $A$. californicus brachyphallus Mead, A. columbianus, A. dolichophallus Mead, A. stamineus Hemphill, and a new species recently discovered at Mt. Palomar in San Diego County (John S. Pearce, pers. comm.).

The genus Hesperarion Simroth is similar to Ariolimax, but species of the former are smaller as mature adults. Hesperarion hemphilli (Binney), H. niger (Cooper), and H. plumbeus (Roth) are known from California (Roth and Sadeghian 2006). Anadenulus cockerelli (Hemphill) is the sole representative of the genus in California and has been collected in Kern, Los Angeles, Orange, and San Diego Counties (Roth and Sadeghian 2006). One unusual member of the native slug fauna is the genus Prophysaon, which is known for its ability to self-amputate a portion of its tail. There are four species recorded from the state, Prophysaon fasciatum Cockerell in W. G. Binney, $P$. andersoni (Cooper), P. dubium Cockerell, and a new species recently discovered in Siskiyou County (Roth and Sadeghian 2006). 
The externally shelled Binneya notabilis Cooper (sole member of the genus in California) is known only from Santa Barbara Island and from empty shells collected on San Nicolas Island (Roth and Sadeghian 2006). Although the genus Deroceras Rafinisque is represented in California by both native and invasive species, the status of the native D. monentolophus Pilsbry is questionable; see D. laeve (Müller), below, for details. For additional information on these native species, including photographs, see Forsyth (2004) and Forsyth's online article, Key to Slugs of British Columbia (http://www.ou.edu/cas/botany-micro/ben/ ben320.html).

\section{INVASIVE SPECIES}

\section{A. Family Agriolimacidae}

(1) Deroceras laeve (Müller, 1774) - Figure 11

Common names: Marsh slug and meadow slug.

Distribution in California: 14 counties: Alameda, Lake, Los Angeles (including Santa Catalina Island), Marin, Nevada, Placer, Shasta, San Bernardino, San Diego, San Francisco, San Mateo, Santa Barbara (including Santa Cruz Island), Santa Cruz (Roth and Sadeghian 2006), and Humboldt.

Global distribution: A Holarctic species native to Asia, Europe, and the Americas from the Arctic to the Andes (Forsyth 2004). Deroceras laeve has also been introduced to most regions of the world, including the tropics and oceanic islands (Quick 1960, Barker 1999).

Ecology: A very catholic species that occupies a huge range of habitats (from sea level to $11,500 \mathrm{ft}$ ), can tolerate freezing temperatures (Barker 1999), and is partially amphibious (Chichester and Getz 1969). It feeds on living and dead plants, feces, carrion, and living animals such as earthworms and aphids (Barker 1999), and is a known horticultural pest (Alicata 1950). It is likely that native populations of this species in California are found in remote wetlands while invasive populations occur in more synanthropic situations such as gardens, parks, nurseries, and greenhouses. Given the huge range and variability in the genitalia of this species, some authors have suggested that $D$. laeve may comprise a species complex (Quick 1960, Hoffmann 1983).

Description: Small, slim slugs up to $25 \mathrm{~mm}$ in length. Mantle is approximately one-half the length of the body. Mucus is colorless (Barker 1999). In California, the body usually is dark brown but can be gray, light brown, or black. Sole tends to be light brown. The penis of $D$. laeve is very variable but is usually long and slender with a simple appendage. However, some individuals may be solely female with vestigial male reproductive organs (Kerney and Cameron 1979). This aphallic form is common in greenhouses in Europe.

Similar species: In California, D. laeve can easily be confused with $D$. panormitanum (Lessona and Pollonera) and D. monentolophus. However, the structure of the penis of $D$. panormitanum distinguishes it from D. laeve (see below). Although a pale-rimmed pneumostome has often been cited (e.g., Barker 1999) as a reliable character for distinguishing $D$. laeve (where it is absent) from $D$. panormitanum (where it is generally present), we have found specimens of the latter in California that lack this trait and specimens of the former that do show a pale rim. De Winter (1988) cited the shape of the tip of the tail as a considerably more reliable character. In D. panormitanum it rises vertically from the foot and may curve backward, while in D. laeve the tail tip slopes forward.

Deroceras monentolophus is thought to be a native species in California; there are also some records from Seattle, Washington (Pilsbry 1948). According to Pilsbry, this species "differs from $D$. laeve by the more uniform diameter of the penis, [and] the part above the sac [atrium] which contains the stimulator is occupied by a single large ridge or pilaster, not a pair of pilasters, such as are always present in $D$. laeve." However, given the enormous variability in the genital structure of $D$. laeve, it is possible that $D$. monentolophus is a variant of this species. Additional morphological and molecular research is needed before the true identity of $D$. monentolophus can be revealed.

(2) Deroceras panormitanum (Lessona and Pollonera, 1882) - Figure 10

Common names: Brown field slug and long-neck field slug.

Distribution in California: 5 counties: Alameda, Contra Costa, Los Angeles, San Francisco, and Santa Clara (Roth and Sadeghian 2006).

Global distribution: Australia, Canada, Europe (including Canary Islands), New Zealand, the United States, southern Africa, and South America (Barker 1999, Forsyth 2004). It is native to southwestern Europe (Kerney and Cameron 1979).

Ecology: Synanthropic species, common in gardens, parks, greenhouses, pastures, roadsides, arable land, and disturbed forest (Barker 1999). Deroceras 
panormitanum feeds on both living and dead plants and is a serious pest of horticulture, pasture, gardens, and crop systems including asparagus and lettuce (Barker 1999).

Description: Small, slim slugs up to $30 \mathrm{~mm}$ in length. Mantle is approximately one-third the length of the body. Mucus is colorless (Barker 1999). In California the body is usually brown but can also be gray. Sole usually is light gray. Body wall appears to be thin, which gives specimens a translucent appearance (Forsyth 2004). In profile, the tip of the tail rises up vertically from the sole and may curve backward (de Winter 1988). The penis of D. panormitanum is bilobed with four to six flagella occurring between the lobes (Forsyth 2004; Kerney and Cameron 1979).

Similar species: See D. laeve and D. monentolophus, above.

(3) Deroceras reticulatum (Müller, 1774) - Figures 7 and 9

Common name: Gray field slug.

Distribution in California: 24 counties: Alameda, Butte, Calaveras, Contra Costa, Del Norte, Los Angeles, Marin, San Bernardino, San Francisco, Tulare, Santa Clara, Ventura (Roth and Sadeghian 2006), Humboldt, Imperial, Kern, Monterey, Sacramento, San Luis Obispo, Shasta, San Mateo, Santa Barbara, Santa Cruz, Sonoma, and Riverside.

Global distribution: This species has a wide distribution and is found in most temperate and subtropical regions (Roth and Sadeghian 2006) including Asia, Australia, Canada, Europe, New Zealand, the United States, South Africa, South America, and islands of the Pacific and Atlantic Oceans (Gordon 1994, Barker 1999). Its native range is thought to be western Europe (Forsyth 2004).

Ecology: It has a wide ecological range but is most abundant in disturbed environments such as gardens, garbage piles, parks, roadsides, hedges, ditches, pasture, and arable land (Barker 1999). Deroceras reticulatum is a very serious agricultural and horticultural pest (South 1992), targeting seedlings, vegetable crops such as cabbage, fruit including strawberries and grapes, and cereals such as wheat (Godan 1983, Martin and Kelly 1986, Gordon 1994, Barker 1999).

Description: A medium-sized slug up to $50 \mathrm{~mm}$ in length (Barker 1999). In California, specimens are predominantly gray (see Figure 9) but can be cream (see Figure 7), both with dark reticulations. Mucus clear but becoming milky-colored when the slug is continuously disturbed (poke the slug gently with an artist's paintbrush). The penis is relatively large, constricted in the middle (which gives it a bilobed appearance), and has a single flagellum that may have a number of bulbous branches (Forsyth 2004, Barker 1999).

Similar species: This species is unlikely to be confused with any other species in California, but in Europe there are many similar species, including Deroceras agreste (L), which tends to prefer wetter sites (Quick 1960). The structure of the penis of $D$. reticulatum (see above) can be used to distinguish it from such closely related species. In $D$. agreste, the penis is simple and has a single, short, unbranched flagellum.

\section{B. Family Arionidae}

(1) Arion distinctus Mabille, 1868 - Figure 14

Remarks: This species is part of a species complex (Davies 1977, 1979) containing A. distinctus, A. hortensis s.s., and A. owenii Davies. Prior to taxonomic separation (Davies 1977, 1979), all three species were inadvertently grouped together under the name Arion hortensis s. 1. This being the case, pre-1977 records of A. hortensis should be considered with caution.

Common names: Darkface Arion or Mabille's orange-soled slug.

Distribution in California: 5 counties: Contra Costa, Alameda (Roth and Sadeghian 2006), San Luis Obispo, San Mateo, and Riverside. Although Backeljau and Van Beeck (1986) state that $A$. distinctus is the commonest species within the complex, our surveys suggest that in California A. hortensis is more abundant.

Global distribution: The Azores, Europe, the United States, New Zealand (Barker 1999), and Canada (Forsyth 2004). It is native to western Europe (Roth and Sadeghian 2006).

Ecology: A common species in disturbed habitats such as gardens and parks (Pfleger 1999). Arion distinctus is a pest of vegetables (Barker 1999).

Description: A medium-sized slug up to $40 \mathrm{~mm}$ in length. The sole and body mucus are yellow to orange and very sticky (Barker 1999). The body color of specimens we have encountered in California is predominantly yellowish brown, but in other areas this species is dark or bluish gray (Forsyth 2004). Tentacles are bluish black. The tip of the tail on the dorsal surface tends to be the same color as the body (Pfleger 1999). Back color does not contrast with lower sides. Right mantle band has a break above the pneumostome. 
Similar species: In California this species can easily be confused with $A$. hortensis, but the structure of the genitals can be used to reliably separate the two species. According to Backeljau and Van Beeck (1986), the shape of the epiphallus structure (i.e., the structure associated with the outlet of the epiphallus in the atrium) is the most reliable diagnostic character. In A. distinctus it is an obvious conical structure that protrudes into the atrium and covers the outlet of the epiphallus. A gutter or fissure (best seen from above) runs from the margin of the epiphallus structure to its center (Backeljau and Van Beeck 1986). Arion owenii appears to be the rarest member of the complex in Europe (Backeljau and Van Beeck 1986) and it has yet to be reported from the United States. The epiphallus structure in this species is variable, but it is generally long, slender, and tongue-like, and protrudes from the outlet of the epiphallus. See below for details of this structure in A. hortensis.

(2) Arion hortensis d'Audebard de Férussac, 1819 - Figure 15

Remarks: See A. distinctus above.

Common names: Garden slug or Férussac's orangesoled slug.

Distribution in California: 12 counties: Marin, San Francisco, Alameda (Roth and Sadeghian 2006), Humboldt, Kern, Sacramento, San Luis Obispo, San Mateo, Santa Barbara, Santa Cruz, Sonoma, and Riverside.

Global distribution: Europe, North America, and New Zealand (Barker 1999). It is native to western and southern Europe (Roth and Sadeghian 2006).

Ecology: Common in many disturbed habitats including gardens, roadsides, forest fringes, and grassy areas within forests (Barker 1999). It is a known pest of a wide range of vegetable crops (reviewed by South 1992 and Barker 1999), horticultural crops (South 1992), pasture (Barker 2002), and sunflowers (Ballanger and Champolivier 1996).

Description: A medium-sized slug up to $50 \mathrm{~mm}$ in length. The sole and body mucus are yellow to bright orange and very sticky (Barker 1999). In California, the predominant body color is dark blue to black, but we have also encountered gray and gray-brown specimens. Tentacles are faintly reddish. The tip of the tail on the dorsal surface is generally the same color as the sole mucus (Pfleger 1999). The color of the sides below the lateral bands is contrasting and pale. There is never a break in the right mantle band above the pneumostome. In A. hortensis, the epiphallus structure is a relatively inconspicuous, oblong plate that covers about half of the epiphallus outlet. It never has a gutter/fissure (Backeljau and Van Beeck 1986).

Similar species: Arion distinctus and A. owenii (see above).

(3) Arion intermedius Normand, 1852 - Figure 13

Common names: Hedgehog Arion or glade slug.

Distribution in California: 6 counties: Marin, San Francisco, Alameda, Monterey, Ventura, and Riverside (Roth and Sadeghian 2006).

Global distribution: The Azores (Quick 1960), Australia, Europe, New Zealand, the United States, South Africa (Barker 1999), Canada, North Africa, and Polynesia (Forsyth 2004). Its native range is central and western Europe (Barker 1999).

Ecology: Occurs in fields, grassy roadsides, gardens (Forsyth 2004), pasture (Quick 1960), hedges, and woods (Kerney and Cameron 1979). Barker (1999) stated that this species tends to be solitary as opposed to gregarious. In Kentucky however, Mc Donnell et al. (in press) collected A. intermedius in large groups of up to 65 individuals on the edge of an oak-maple forest. It feeds on green plants and fungi (Forsyth 2004). According to Barker (1999) and Glen, Wiltshire, and Milsom (1984), this species may not be pestiferous, but Christian et al. (1999) cited it as a pest of wheat and Barker (2002) highlighted it as a pest of pasture due to its effects on plant productivity.

Description: This is the smallest slug that we have encountered in California, measuring $25 \mathrm{~mm}$ or less. In the state, the predominant body color of this species is light gray-yellow with distinctly darker tentacles. Other color morphs have been reported in other parts of the world, such as a greenish yellow type (Barker 1999). The sole is grayish yellow and the body mucus is golden yellow (Forsyth 2004). Arion intermedius is most reliably separated from other species based on the presence of small spikes on the tubercles that give the slug a prickly appearance when it is contracted (Kerney and Cameron 1979). Internally, there is no ligula within the atrium (Quick 1960).

Similar species: This species, with its very small size and prickly appearance, is unlikely to be confused with any other slug in California. 
(4) Arion rufus (Linnaeus, 1758) - Figure 12

Common names: Chocolate Arion or red slug.

Distribution in California: 3 counties: Del Norte, Sonoma (Roth and Sadeghian 2006), and Humboldt.

Global distribution: Canada (Forsyth 2004), Europe, and the United States. It is native to western and southern Europe (Roth and Sadeghian 2006).

Ecology: Common in disturbed habitats such as campsites, gardens, and parks (Forsyth 2004). In Europe it is also found in damp woodlands (especially coastal forests) and meadows. We have found this slug in large numbers in coastal redwood forests north of Eureka in California, especially in areas of forest that have been disturbed by human habitation. It is omnivorous, feeding on fungi, feces, carrion and both dead and living plants (Pfleger 1999, Forsyth 2004).

Description: A very large slug up to $180 \mathrm{~mm}$ (Forsyth 2004). In California, the body color tends to be brown to light orange. The distinct foot fringe is usually bright orange with black vertical lines (see Figure 12). The head and tentacles also tend to be darker than the rest of the body. The body mucus usually is light orange in Californian specimens while the sole mucus is colorless. Specimens sometimes display a rocking behavior when disturbed.

Similar species: Arion rufus is unlikely to be confused with any other slug in California, but in Europe it is similar to Arion ater (Linnaeus). The two species can be reliably distinguished, however, on the basis of genital characteristics. Arion rufus has a large, relatively unsymmetrical atrium with a large ligula

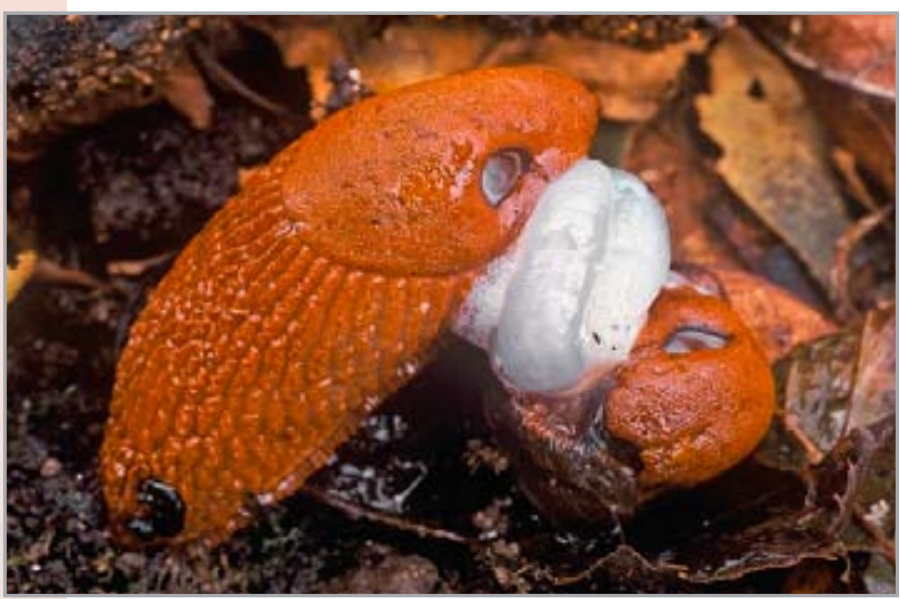

Figure 20. Arion lusitanicus Mabille (= vulgaris Moquin-Tandon) in copula. Species not yet reported from the United States, but likely to be collected in the future. A very serious agricultural pest elsewhere. Photograph by Roy Anderson. (situated inside the atrium); this contrasts with the smaller, more symmetrical atrium and smaller ligula of $A$. ater (Quick 1960, Noble 1992). Arion ater usually is dark in color while rufus, as its name suggests, tends to be red or orange, at least in warmer climates. In Europe, A. rufus may also be confused with the severe pest $A$. lusitanicus (= vulgaris Moquin-Tandon) (Figure 20). The ligula of the latter is located inside the distal part of its oviduct, giving it a conspicuous, swollen appearance, and the point of insertion of the epiphallus and spermathecal duct is lower on the atrium than in A. rufus (Noble 1992). It is also worth highlighting that hybrids between $A$. ater and $A$. rufus (Noble 1992) and between A. ater and A. lusitonicus (Hagnell, Schonder, and von Proschwitz 2003) have been reported in Europe.

\section{(5) Arion silvaticus Lohmander, 1937 - Figure 16}

Common name: Forest Arion.

Distribution in California: 1 county: San Francisco (Roth and Sadeghian 2006).

Global distribution: Canada (Forsyth 2004), Europe, and the United States. It is native to Europe.

Ecology: It is found in gardens, parks, and other disturbed areas (Forsyth 2004). It appears to be an uncommon species in California, with records only from San Francisco.

Description: A medium-sized slug up to $40 \mathrm{~mm}$ in length. Body tends to be gray above, fading to white on the sides. There is also an obvious broad, dark, lateral band on each flank. Body and sole mucus are colorless (Kerney and Cameron 1979). The sole is opaque white. Internally, A. silvaticus has an unpigmented epiphallus (Forsyth 2004).

Similar species: It is unlikely that this species would be confused with other slugs currently known from California, but there are other European invasive species that are very similar. The unpigmented epiphallus of $A$. silvaticus distinguishes it from the speckled epiphallus of Arion circumscriptus. Arion silvaticus is also similar to Arion fasciatus (Nilsson), but the latter has a distinct yellowish flush just below the lateral bands and a narrower oviduct than $A$. silvaticus (Kerney and Cameron 1979). 
(6) Arion subfuscus (Draparnaud, 1805) - Figure 6

Common name: Dusky slug.

Distribution in California: This species was recently discovered in California by the authors. 3 counties: Humboldt, San Mateo, and Sonoma.

Global distribution: Canada, Europe, the United States (Forsyth, 2004), Asia, and South America. Its native range is northern and western Europe (Roth and Sadeghian 2006).

Ecology: In Europe this species frequents various types of forests (including pine woods) where it feeds on fungi, living plants, carrion, and excreta (Pfleger 1999). It also occurs in damp hedgerows, pastures, waste ground, roadsides, gardens, peat bogs, and dunes (Quick 1960, Kerney and Cameron 1979, Pfleger 1999, Forsyth 2004). It appears to be tolerant of high altitudes and has been collected in the Alps at 2,500 $\mathrm{m}$ (Kerney and Cameron 1979). According to South (1992), A. subfuscus may not be a significant pest, but Godan (1983) cites it as a pest of potatoes, rape, and greenhouse cucumbers.

Description: A medium to large slug, up to $70 \mathrm{~mm}$ in length (Forsyth 2004). In California, specimens tend to be orange-brown with darker lateral bands. Body mucus is sticky and usually orange-yellow. Sole is light yellow with colorless mucus. Foot fringe is distinctly lineolated. This species is unable to contract into a hemispherical shape when disturbed (Cameron, Eversham, and Jackson 1983).

Similar species: Arion subfuscus s.l. is known to comprise a species complex (Pinceel et al. 2004) with two distinct species: Arion subfuscus s.s. and Arion fuscus (Müller). The species can be distinguished using the position of the genitalia relative to the digestive gland. For A. subfuscus, the large, pale genitalia are located on the periphery of the digestive gland, while those of A. fuscus are small, dark, and embedded within the gland.

\section{Family limacidae}

(1) Lehmannia valentiana (d'Audebard de Férussac, 1823)

- Figure 19

Common names: Valencia slug or three-band garden slug.

Distribution in California: 29 counties: Alameda, Butte, Contra Costa, Kings, Lake, Los Angeles (including Santa Catalina Island), Madera, Modoc, Orange, Sutter, San Bernardino, San Francisco, Santa Barbara (including Santa Cruz Island), Tehama, Santa Clara, San Diego, Ventura (including San Nicolas Island) (Roth and Sadeghian 2006), Fresno, Humboldt,
Imperial, Kern, Monterey, Sacramento, San Luis Obispo, Shasta, San Mateo, Santa Cruz, Sonoma, and Riverside.

Global distribution: Australia, Canada, Europe, New Zealand, the United States (including Hawaii), South Africa, South America, and the Pacific islands of Rapa Nui and Juan Fernándes (Barker 1999, Forsyth 2004). It is native to the Iberian Peninsula in Europe (Roth and Sadeghian 2006).

Ecology: This is a strictly terrestrial slug species, unlike other Lehmannia Heynemann, which are arboreal (Barker 1999). It feeds on plants and decomposing wood and is a very serious pest of flowers such as orchids and other ornamentals in greenhouses (South 1992). Kerney and Cameron (1979) also cite it as a pest of urban gardens. The species appears to be intolerant of a cold climate (Forsyth 2004).

Description: A medium to large slug, up to 75 $\mathrm{mm}$ in length (Barker 1999). The ground color of L. valentiana is very variable but in California it is usually cream, though it can also be dark brown. The species can be identified by the presence of two distinct, dark "tram" lines on the back, often running the full length of the body (see Figure 19). There may also be a less distinct median band. However, we have collected many specimens where the bands are broken into spots and others where the lines are very faint (usually in large specimens). The mucus of this species is watery, copious, and colorless. Internally, the penis has a short, blunt flagellum (Forsyth 2004).

Similar species: In California, L. valentiana may be confused with Limax maximus L., but the latter is larger, has sticky mucus, and never has bands on the mantle (see the L. maximus description below for extra details). In addition, Europe has many similar species that may eventually be introduced accidentally into California. Lehmannia nyctelia (Bourguignat) is almost identical to $L$. valentiana except that its penis does not have a flagellum. However, in California we have occasionally collected $L$. valentiana specimens where the flagellum has been inverted into the penis, giving the appearance of L. nyctelia. In cases where no flagellum is apparent, collectors are welcome to send specimens to the senior author for confirmation. Lehmannia marginata (Müller) has also been confused with $L$. valentiana, but can be distinguished by the short, tapering flagellum on its penis and a pale median line that runs the length of its tail (Kerney and Cameron 1979). 
(2) Limacus flavus (Linnaeus, 1758) - Figure 17

Common names: Yellow cellar slug or yellow garden slug.

Distribution in California: 19 counties: Alameda, Butte, Contra Costa, Los Angeles (including Santa Catalina Island), Marin, Orange, Sacramento, San Bernardino, San Francisco, San Luis Obispo, San Mateo, Santa Barbara, Santa Clara, Tulare, Ventura (Roth and Sadeghian 2006), Imperial, Kern, Santa Cruz, and Riverside.

Global distribution: Australia, Canada, China, Cook Islands, Europe, Ghana, Japan, Madagascar, Middle East, New Zealand, North Africa, the United States, South Africa, South America, Rarotonga, the island of St. Helena, and Vanuatu (Quick 1960, Barker 1999, Forsyth 2004, Roth and Sadeghian 2006). It is native to Europe (Roth and Sadeghian 2006).

Ecology: Synanthropic. A highly invasive species, as highlighted by the global distribution described above. However, it appears to be a secretive slug, is nocturnal, and hides in dark, damp crevices during the day (Pfleger 1999). In California, we commonly find this species in sprinkler valve boxes and in aggregations of up to 40 individuals. Other habitats reported for L. flavus include cellars, outhouses, structural crevices, wood stacks, compost heaps, and gardens (Barker 1999, Forsyth 2004), and in Europe it is found in woodlands where it takes cover under bark and logs. Limacus flavus feeds on decaying plant and vegetable matter, fungi, lichens, mildew, and garbage (Quick 1960). It appears to be an occasional pest in residential and commercial areas (Barker 1999), and Godan (1983) cited it as pestiferous on stored agricultural produce such as apples, pears, pumpkins, carrots, and potatoes.

Description: A large slug, up to $120 \mathrm{~mm}$ in length (Barker 1999). In California, all of the specimens that we have encountered are mottled yellow and green. Body mucus is also yellow, but the sole mucus is colorless. Tentacles are petrol blue. The keel is weak and rounded and tends to be marked by a median yellow line. The penis of L. flavus is long and has 2 to 3 kinks, and the spermathecal duct joins at the apex of the oviduct (Kerney and Cameron 1979).

Similar species: This species is very unlikely to be confused with any others in California, but in Europe it is very similar to Limacus maculatus (Kaleniczenko). The latter does not have the yellow median stripe on the tail and its penis is shorter and C-shaped or has a single kink. The spermathecal duct of $L$. maculatus joins at the base of the penis (Kerney and Cameron 1979).

(3) Limax maximus Linnaeus, 1758 - Figure 18

Common names: Tiger slug, great gray slug, and giant garden slug.

Distribution in California: 13 counties: Alameda, Calaveras, Humboldt, Kern, Los Angeles, Marin, Orange, Sacramento, San Bernardino, San Diego, San Francisco, Santa Barbara (including Santa Cruz Island), and Santa Clara (Roth and Sadeghian 2006).

Global distribution: Asia Minor, Australia, Canada, Europe, Mexico, New Zealand, the United States (including Hawaii and Alaska), Africa, and South America (Barker 1999, Roth and Sadeghian 2006). It is native to Europe, North Africa, and Asia Minor (Roth and Sadeghian 2006).

Ecology: Synanthropic, occurring in gardens, outhouses, damp cellars, greenhouses, wooded areas near human habitation, pasture, parks, tunnels, and underground conduits (Quick 1960, Pfleger 1999, Barker 1999). This is also a strictly nocturnal species (Forsyth 2004). It is not gregarious, but is aggressive toward other slugs and it may be cannibalistic (Gordon 1994). Limax maximus tends to feed on fungi, carrion, and decaying plants, but it may also be a pest of horticultural and agricultural crops (Barker and McGhie 1984).

Description: A very large slug up to $200 \mathrm{~mm}$ in length (Barker 1999). Body color pale brown to yellowish gray, often with a number of dark lateral bands on the tail, though these are often broken up into spots. The mantle never has bands, only dark spots or marbling (Forsyth 2004). Antennae are typically reddish brown (Kerney and Cameron 1979). Body and sole mucus is colorless and sticky. Keel is acute and usually well marked. Internally, L. maximus has a large, convoluted penis (Barker, 1999).

Similar species: In California, this species may be confused with Lehmannia valentiana, but the latter is smaller, has watery mucus, and typically has bands on its mantle (see the L. valentiana description above for extra details). 


\section{Family Milacidae}

(1) Milax gagates (Draparnaud, 1801) - Figures 8a and 8b Common names: Greenhouse slug and jet slug. Distribution in California: 23 counties: Alameda, Butte, Contra Costa, Kern, Lake, Los Angeles (including Santa Catalina Island), Napa, Orange, Sacramento, San Bernardino, San Diego, San Francisco, Santa Barbara (including Santa Cruz Island), Santa Clara, Santa Cruz, Stanislaus, Tehama, Trinity, Ventura (including Anacapa Island) (Roth and Sadeghian 2006), Monterey, San Luis Obispo, San Mateo, and Riverside.

Global distribution: Australia, Europe, Japan, Mexico (including Baja California), New Zealand, the United States, South Africa, South America, Atlantic islands (e.g., Bermuda and St. Helena), and Pacific islands (e.g., Juan Fernandes and Rapa Nui) (Gordon 1994, Barker 1999, Roth and Sadeghian 2006). This species is probably native only to the coastal zone and islands of the western Mediterranean and the Canary Islands (Barker 1999).

Ecology: Milax gagates is found mainly in disturbed habitats such as gardens, nurseries, pasture, and arable land. In its native range it is also found in woodlands, hedges, and grassy areas close to the sea (Kerney and Cameron 1979). This is chiefly a subterranean slug and is a pest of root crops such as carrots and potatoes (Barker 1999). It is also a common pest in greenhouses in cooler climes (Gordon 1994).

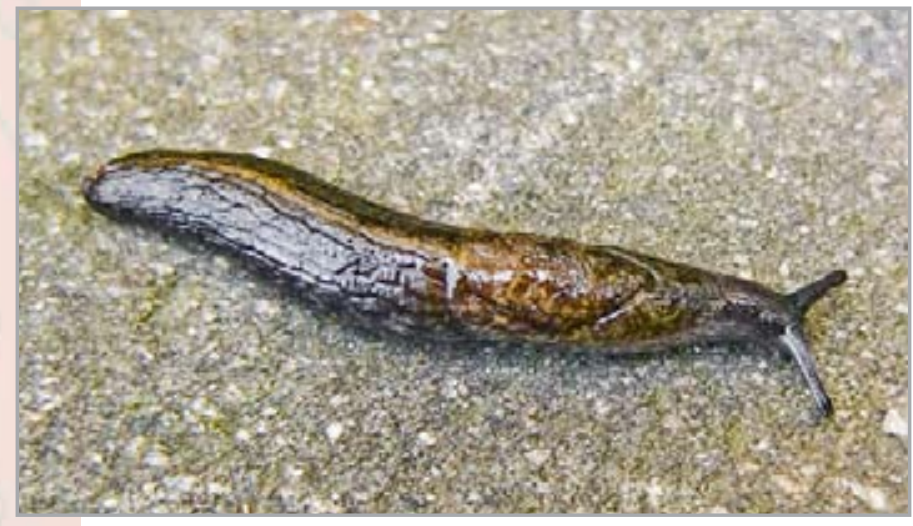

Figure 21a. Tandonia budapestensis (Hazay). Recently reported for the first time in the United States (Reise et al., 2006) and likely to show up eventually in California. Also a serious pest of agriculture. Photograph by Michal Maňas.
Description: A medium-sized slug up to $50 \mathrm{~mm}$ long with no lateral bands (Barker 1999). Body color usually is dark gray to black but we have collected lighter-colored forms in California (Figure 8). The keel (which runs from the end of the mantle to the tip of the tail) usually is of a color similar to or darker then the body, but it can also be lighter in color. The body and sole mucus are colorless. Internally, the stimulator, which is located within the atrium, is long and curved (Barker 1999, Kerney and Cameron 1979).

Similar species: This is the only milacid known to occur in California. However, in Europe there are many similar species that are invasive and known agricultural pests. These include Tandonia budapestensis (Figure 21a), which has a dark median stripe on the sole (Figure 21b) (Pfleger 1999). This species also assumes a C-shape when at rest or when threatened (Cameron, Eversham, and Jackson 1983) and has no atrial stimulator (Barker 1999). Tandonia sowerbyi (Férussac) has a thick, blunt stimulator, its respiratory pore has a pale rim, and its mucus is yellow (Kerney and Cameron 1979). Boettgerilla pallens (Simroth) is also very invasive (Kerney and Cameron 1979), and collectors should be alert to the possible future introduction of this species to the state. The species is wormlike and grayish blue with a darker keel (Forsyth 2004), making it very unlikely to be confused with any other slug.

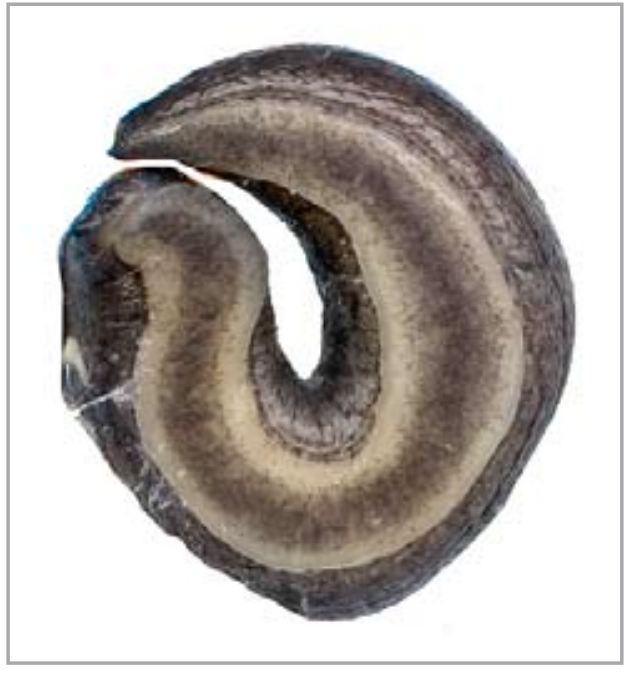

Figure 21b. Sole of Tandonia budapestensis (Hazay), showing dark median stripe. Photograph by Roy Anderson. 


\section{E. Family Testacellidae}

(1) Testacella haliotidea Draparnaud, 1801 - Figure 4 Common names: Shelled slug and earshell slug. Distribution in California: 3 counties: Alameda, Contra Costa, and Marin (Roth and Sadeghian 2006).

Global distribution: Australia, Canada, Cuba, New Zealand, and the United States (Barker 1999, Forsyth 2004, Roth and Sadeghian 2006). It is native to Europe and North Africa (Barker 1999).

Ecology: Testacella haliotidea is carnivorous, feeding on invertebrates including earthworms, snails, and other slugs (Barker 1999). On encountering prey, it impales it with its radula and then consumes it whole (Quick 1960). During the day it rests underground and in very dry and cold conditions it can burrow to depths of over $1 \mathrm{~m}$ where it aestivates in a specially constructed cell lined with mucus (Barker 1999). Since it does not feed on plant material, it is not regarded as an agricultural or horticultural pest. However, its impact on beneficial earthworm populations is in need of research. In Europe it is found mainly in gardens, parks, and cultivated land (Kerney and Cameron 1979). Given its subterranean and nocturnal habits, the distribution of T. haliotidea may be underrecorded in California.

Description: A large slug up to $120 \mathrm{~mm}$ in length with a small external shell located at the posterior end. Body color is grayish brown to yellow with colorless mucus. Testacellids have two distinct, branched, lateral grooves that originate from the anterior edge of the shell. In T. haliotidea these are separated by approximately $2 \mathrm{~mm}$ at their point of origin (Barker 1999). Internally, the penis has a flagellum and the spermathecal duct is short and thick (Quick 1960).

Similar species: The only other slug with an external shell known to occur in California is B. notabilis, but this native species has only been collected on Santa Barbara Island and San Nicolas Island (Roth and Sadeghian 2006) and its shell is relatively large and whorled. In Europe, there are two species similar to $T$. haliotidea: Testacella maugei Férussac has a larger shell, lateral grooves that are separated by approximately $5 \mathrm{~mm}$ at their point of origin, no penile flagellum, and a spermathecal duct that is long and thin (Quick 1960); Testacella scutulum Sowerby has a shell similar to that of T. haliotidea but does not have a flagellum on the penis and the size of its spermathecal duct is intermediate between those of T. maugei and $T$. haliotidea (Quick 1960).

\section{F. Family Veronicellidae}

(1) Veronicella cubensis (Pfeiffer, 1840) - Figure 5

Common name: Cuban slug.

Distribution in California: 1 county: Santa Barbara (Mc Donnell et al. 2008)

Global distribution: It is thought that $V$. cubensis is native to Cuba (Robinson and Hollingsworth 2004), but it has also been introduced to Jamaica (Baker 1925), the Bahamas, Haiti, the Dominican Republic, Puerto Rico, Guam (Thomé 1993a), Antigua, Saint Kitts and Nevis, Dominica, Barbados (West Indies), St. Croix, Olosega (Manu'a Islands), Tutuila (American Samoa), Pohnpei (Micronesia), Rota, the Northern Mariana Islands (Robinson and Hollingsworth 2004), and Hawaii (Thomé 1993b). There are also records for mainland North America (interceptions in New Orleans and Florida [Thomé 1993a] and our record in California).

Ecology: The species is an extremely serious agricultural and horticultural pest on Hawaii (Hata, Hara, and $\mathrm{Hu}$ 1997), Rota, and Guam. On Rota, it is found in virtually all habitats from relatively undisturbed natural habitat to agricultural and suburban areas (Robinson and Hollingsworth 2004). Veronicella cubensis has been recorded as feeding on a wide range of cultivated plants including banana, beans, cassava, citrus, coffee, mango, melon, orchids, papaya, passion fruit, pepper, pumpkin, and tobacco (Anon. 2006, Robinson and Hollingsworth 2004, Maceira 2002).

Description: A large slug measuring up to $120 \mathrm{~mm}$ in length. Although it has highly variable coloration (including an albino form), the notum of $V$. cubensis is usually dark to pale brown, generally with a pale dorsomedian line (see Figure 5). It often has black speckles, which sometimes fuse to form two lateral bands (Robinson and Hollingsworth 2004). The penis has a characteristic flaring that produces a blade-like structure down each side and the penile gland has numerous, very long tubules that may fill up to one third of the body cavity. There is no accessory gland (David G. Robinson, pers. comm.).

Similar species: Although V. cubensis is the only member of the family known from California, other invasive veronicellids have been collected and intercepted in other parts of the United States. These include the Florida leatherleaf, Leidyula floridana (Leidy). The penis of this species lacks the blade-like structure of $V$. cubensis and it has an obvious accessory gland located internally on the body wall where the posterior genitalia meet the genital pore (David G. Robinson, pers. comm.). 


\section{References}

Aguiar, P. H., P. Morera, and J. Pascual. 1981. First record of Angiostrongylus cantonensis in Cuba. American Journal of Tropical Medicine \& Hygiene 30(5):963-965.

Alicata, J. E. 1950. Observations on the biology and control of a garden slug injurious to orchids in Hawaii. Pacific Orchid Society, Hawaii 8:279-285.

Anderson, R. 2005. An annotated list of the non-marine Mollusca of Britain and Ireland. Journal of Conchology 38:607-637.

Anon. 2006. Pest Alert. Stop the spread of the Cuban Slug! Plant Protection and Quarantine. United States Department of Agriculture. Animal and Plant Health Inspection Service. 2 pp.

Backeljau, T., and M. Van Beeck. 1986. Epiphallus anatomy in the Arion hortensis species aggregate (Mollusca, Pulmonata). Zoologica Scripta 15:61-68.

Baker, H. B. 1925. North American Veronicellidae. Proceedings of the National Academy of Sciences, Philadelphia 77:157-84.

Ballanger, Y., and L. Champolivier. 1996. Slug damage to sunflower crops in the southwest of France. Pp. 321-326 in I. F. Henderson, ed. Slug and Snail Pests in Agriculture, Symposium Proceedings Number 66. British Crop Protection Council, Farnham, U.K.

Barker, G. M. 1999. Naturalised Terrestrial Stylommatophora (Mollusca: Gastropoda). Fauna of New Zealand, Number 38. Manaaki Whenua Press, Canterbury, New Zealand. 254pp.

Barker, G. M. 2002. Gastropods as pests in New Zealand pastoral agriculture, with emphasis on Agriolimacidae, Arionidae, and Milacidae. Pp. 361-423 in G. W. Barker, ed. Molluscs as Crop Pests. CAB International Publishing, Wallingford, U.K.

Barker, G. M., and R. A. McGhie. 1984. The biology of introduced slugs (Pulmonata) in New Zealand. 1. Introduction and notes on Limax maximus. The New Zealand Entomologist 8:106-111.

California Department of Food and Agriculture. 2006. California Agricultural Resource Directory 2006. CDFA, Sacramento, California. 178 pp.

Cameron, R. A. D., B. Eversham, and N. Jackson. 1983. A field key to the slugs of the British Isles. Field Studies 5:807-824.

Chichester, L. F., and L. L. Getz. 1969. The zoogeography and ecology of arionid and limacid slugs introduced into northeastern North America. Malacologia 7:313-346.

Christian, D. G., E. T. G. Bacon, D. Brockie, D. Glen, R. J. Gutteridge, and J. F. Jenkyn. 1999. Interactions of straw dispersal methods and direct drilling or cultivations on winter wheat (Triticum aestivum) grown on a clay soil. Journal of Agricultural Engineering Research 73:297-309.

Davies, S. M. 1977. The Arion hortensis complex, with notes on Arion intermedius Normand. Journal of Conchology 29:173-187.

Davies, S. M. 1979. Segregates of the Arion hortensis complex (Pulmonata: Arionidae), with the description of a new species, Arion owensii. Journal of Conchology 30:123-127.

de Winter, A. G. 1988. Remarks on the non-marine molluscan fauna of the Azores. Basteria 52:105-109.

Forsyth, R. G. 2004. Land Snails of British Columbia. Royal British Columbia Museum, Canada. 188 pp.

Gervais, J. A., A. Traveset, and M. Wilson. 1998. The potential for seed dispersal by the Banana Slug (Ariolimax columbianus). The American Midland Naturalist 140:103-110.

Glen, D. M., C. W. Wiltshire, and N. F. Milsom. 1984. Slugs and straw disposal in winter wheat. Pp. 139-144 in Proceedings of the 1984 British Crop Protection Conference - Pests and Diseases.

Godan, D. 1983. Pest Slugs and Snails: Biology and Control. Springer-Verlag, Berlin, Germany. 445 pp.

Gordon, D. G. 1994. Western Society of Malacologists Field Guide to the Slug. Sasquatch Books, Seattle, Washington. $48 \mathrm{pp}$.

Hagnell, J., C. Schonder, and T. von Proschwitz. 2003. Hybridisation in arionids: The rise of a super slug? Pp. 221-226 in Proceedings of the 2003 British Crop Protection Conference-Slugs and Snails. Agricultural, Veterinary, and Environmental Perspectives. 
Harper, A. B. 1988. The Banana Slug. A Close Look at a Giant Forest Slug of Western North America. Otter B Books, Santa Cruz, California. 32 pp.

Hasan, S., and C. Vago. 1966. Transmission of Alternaria brassicicola by slugs. Plant Disease Reporter 50:764-767.

Hata, T. Y., A. H. Hara, and B. K-S. Hu. 1997. Molluscicides and mechanical barriers against slugs, Vaginula plebeia Fischer and Veronicella cubensis (Pfeiffer), (Stylommatophora: Veronicellidae). Crop Protection 16(6):501-506.

Hoffmann, R. J. 1983. The mating system of the terrestrial slug Deroceras laeve. Evolution 37:423-425.

Kerney, M. P., and R. A. D. Cameron. 1979. A Field Guide to the Land Snails of Britain and Northwest Europe. Harper Collins Publishers, London. 288 pp.

Kroeber, A. L. 1976. Handbook of the Indians of California. Dover Publications, New York. 995 pp.

Leonard, J. L., J. S. Pearse, and A. B. Harper. 2002. Comparative reproductive biology of Ariolimax californicus and A. dolichophallus (Gastropoda: Stylommatophora). Invertebrate Reproduction and Development 41:83-93.

Lindo, J. F., C. T. Escoffery, B. Reid, C. Codrington, C. Cunningham-Myrie, and M. L. Eberhard. 2004. Fatal autochthonous eosinophilic meningitis in a Jamaican child caused by Angiostrongylus cantonensis. American Journal of Tropical Medicine and Hygiene 70(4):425-428.

Lovatt, A. L., and A. B. Black. 1920. The gray garden slug. Oregon Agricultural Experimental Station Bulletin 170:1-43.

Mc Donnell, R. J., T. D. Paine, R. Stouthamer, M. J. Gormally, and J. D. Harwood. In press. Molecular and morphological evidence for the occurrence of two new species of invasive slugs in Kentucky, Arion intermedius Normand, 1852, and Arion hortensis d'Audebard de Férussac, 1819 (Arionidae: Stylommatophora). Journal of the Kentucky Academy of Science.

Mc Donnell, R. J., A. Hansen, T. D. Paine, and M. J. Gormally. 2008. A record of the invasive slug Veronicella cubensis (Pfeiffer, 1840) in California. The Veliger 50(2):81-82.

Maceira, D. F. 2002. Plantas usadas como recurso trófico por Veronicella cubensis (Pfr., 1840) (Gastropoda: Veronicellidae) en dos localidades del Parque Nacional “Alejandro de Humboldt.” Revista Centro Agricola 1(29):82-84.

Martin, T. J., and J. R. Kelly. 1986. The effect of changing agriculture on slugs as pests of cereals. Pp. 411424 in Proceedings of the 1986 British Crop Protection Conference - Pests and Diseases.

Noble, L. R. 1992. Differentiation of large arionid slugs (Mollusca, Pulmonata) using ligula morphology. Zoologica Scripta 21(3):255-263.

Pfleger, V. 1999. A Field Guide in Colour to Molluscs. Blitz Editions, Leicester, U.K. 216 pp.

Pilsbry, H. A. 1948. Land Mollusca of North America (North of Mexico). Academy of Natural Sciences of Philapelphia, Monograph 3. 2(2):521-1113.

Pinceel, J., K. Jordaens, N. Van Houtte, A. J. De Winter, and T. Backeljau. 2004. Molecular and morphological data reveal cryptic taxonomic diversity in the terrestrial slug complex Arion subfuscus/ fuscus. Biological Journal of the Linnean Society 83:23-38.

Quick, H. E. 1960. British Slugs (Pulmonata: Testacellidae, Arionidae, Limacidae). Bulletin of the British Museum (Natural History), Zoology 6(3):103-226.

Raloff, J. 2007. Lettuce liability. Programs to keep salad germ-free, raise wildlife, and conservation concerns. Science News 172:362-364.

Reise, H., J. M. C. Hutchinson, and D. G. Robinson. 2006. Two introduced pest slugs: Tandonia budapestensis new to the Americas, and Deroceras panormitanum new to the eastern USA. The Veliger 48:110-115.

Robinson, D. G., and R. G. Hollingsworth. 2004. Survey of slug and snail pests on subsistence and garden crops in the islands of the American Pacific: Guam and the Northern Mariana Islands. Part 1. The leatherleaf slugs (Family Veronicellidae). Internal Report for U.S. Department of Agriculture and the Government of Mariana Islands. $11 \mathrm{pp}$. 
Roth, B., and P. S. Sadeghian. 2006. Checklist of the Land Snails and Slugs of California. Contributions in Science 3. Santa Barbara Museum of Natural History, California. 82 pp.

South, A. 1992. Terrestrial Slugs. Biology, Ecology, and Control. Chapman and Hall, London. 428 pp.

Sproston, E. L., M. Macrae, I. D. Ogden, M. J. Wilson, and N. J. C. Strachan. 2006. Slugs: Potential novel vectors of Escherichia coli O157. Applied and Environmental Microbiology 72:144-149

Thomé, J. W. 1993a. Erneute Beschreibung von Veronicella cubensis (Pfeiffer 1840) (Gastropoda:). Archiv fuer Molluskenkunde 122:113-121.

Thomé, J. W. 1993b. Estado actual da sistematica dos Veronicellidae (Mollusca; Gastropoda) americanos, com comentários sobre sua importancia económica, ambiental e na saúde. Biociencias, Porto Alegre $1(1): 61-75$.

\section{Other Useful Texts}

Barker, G. M., ed. 2002. Molluscs as Crop Pests. CAB International Publishing, Wallingford, U.K. 468 pp.

Barker, G. M., ed. 2002. Natural Enemies of Terrestrial Molluscs. CAB International Publishing, Wallingford, U.K. 320 pp.

Henderson, I. F., ed. 1989. Slugs and Snails in World Agriculture. Monograph Number 41. British Crop Protection Council, Farnham, U.K. 422 pp.

Henderson, I. F., ed. 1996. Slug and Snail Pests in Agriculture. Symposium Proceedings Number 66. British Crop Protection Council, Farnham, U.K. 450 pp.

Pilsbry, H. A. 1939. Land Mollusca of North America (north of Mexico). Academy of Natural Sciences of Philadelphia, Monograph 3, 1(1):1-573.

Pilsbry, H. A. 1940. Land Mollusca of North America (north of Mexico). Academy of Natural Sciences of Philadelphia, Monograph 3, 1(2):574-994.

Pilsbry, H. A. 1946. Land Mollusca of North America (north of Mexico). Academy of Natural Sciences of Philadelphia, Monograph 3, 2(1):1-520.

Roth, B. 1983. European land mollusks in the San Francisco Bay Area, California: Carychium minimum Müller and the Arion hortensis complex. The Veliger 24(4):342-344.

Roth, B. 1986. Notes on three European land mollusks introduced to California. Bulletin of the Southern California Academy of Science 85(1):22-28.

Runham, N. W., and P. J. Hunter. 1970. Terrestrial Slugs. Hutchinson University Library. London, U.K. 184 pp.

\section{Personal Communications}

John S. Pearse, Professor Emeritus, Ecology and Evolutionary Biology, University of California, Santa Cruz, CA 95060, U.S.A. E-mail: pearse@biology.ucsc.edu

Dr. David G. Robinson, USDA APHIS PPQ, Department of Malacology, Academy of Natural Sciences, 1900 Ben Franklin Parkway, Philadelphia, PA 19103, U.S.A. E-mail: robinson@acnatsci.org

\section{Useful Societies, Web sites, and Programs}

American Malacological Society http://www.malacological.org/

Conchological Society of Great Britain and Ireland http://www.conchsoc.org/

CyberSlug

CyberSlug is an electronic identification guide for slugs designed by Dr. Anthony Cook. Copies are available from the author at the following address: 5 Drumnamallaght Road, Ballymoney, Co. Antrim, Northern Ireland BT53 7QX, United Kingdom. E-mail: A.Cook@ulster.ac.uk

The Malacological Society of London http://www.malacsoc.org.uk/

Molluscan journal and newsletter search engine http://emuweb.fieldmuseum.org/iz/journals.php

Western Society of Malacologists http://biology.fullerton.edu/wsm/ 


\section{Acknowledgments}

This research was funded by the European Union under a Marie Curie Outgoing International Fellowship (MOIF-CT-2005-21592). We are grateful to Roy Anderson, James Harwood, Jack Kelly Clark, and Michal Maňas for use of photographs and to both David Robinson and John Pearse for use of unpublished information. Thanks to Roy Anderson, Gary Barker, James Harwood, Michal Maňas, Barry Roth, and Chris Williams for review comments. Thanks also to Chris Hanlon for providing copies of relevant literature. We are grateful to Allison Hansen and Cheryl Wilen for assistance with field work.

\section{ENGLISH-METRIC CONVERSIONS}

\begin{tabular}{|c|c|c|c|}
\hline English & $\begin{array}{c}\text { Conversion factor for } \\
\text { English to metric }\end{array}$ & $\begin{array}{c}\text { Conversion factor for } \\
\text { metric to English }\end{array}$ & Metric \\
\hline degrees Fahrenheit $\left({ }^{\circ} \mathrm{F}\right)$ & $\left({ }^{\circ} \mathrm{F}-32\right) \div 1.8$ & $\left({ }^{\circ} \mathrm{C} \times 1.8\right)+32$ & degrees Celsius $\left({ }^{\circ} \mathrm{C}\right)$ \\
inch (in) & 25.4 & 0.0394 & millimeter $(\mathrm{mm})$ \\
centimeter $(\mathrm{cm})$
\end{tabular}

\section{For More Information}

You will find related information in these titles and in other publications, slide sets, CD-ROMs, and videos from UC ANR:

Decollate Snails for Control of Brown Garden Snails in Southern California Citrus Groves, Publication 21384

Snails and Slugs: Pest Notes for Home and Landscape, Publication 7427

Snails as Food: Escargot, Publication 2222

To order these products, visit our online catalog at http://anrcatalog. ucdavis.edu. You can also place orders by mail, phone, or FAX, or request a printed catalog of publications, slide sets, CD-ROMs, and videos from

\section{University of California \\ Agriculture and Natural Resources \\ Communication Services \\ 6701 San Pablo Avenue, 2nd Floor \\ Oakland, California 94608-1239}

Telephone: (800) $994-8849$ or (510) $642-2431$,

FAX: (510) 643-5470

e-mail inquiries: danrcs@ucdavis.edu

An electronic version of this publication is available on the ANR Communication Services website at http://anrcatalog.ucdavis.edu.

Publication 8336

ISBN-13: 978-1-60107-564-2

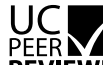

REVIEWED This publication has been anonymously peer reviewed for technical accuracy by University of California scientists and other qualified professionals. This review process was managed by the ANR Associate Editor for Pest Management.

(c) 2009 by The Regents of the University of California
Division of Agriculture and Natural Resources.

All rights reserved.

The University of California prohibits discrimination or harassment of any person on the basis of race, color, national origin, religion, sex, gender identity, pregnancy (including childbirth, and medical conditions related to pregnancy or childbirth), physical or mental disability, medical condition (cancer-related or genetic characteristics), ancestry, marital status, age, sexual orientation, citizenship, or status as a covered veteran (covered veterans are special disabled veterans, recently separated veterans, Vietnam era veterans, or any other veterans who served on active duty during a war or in a campaign or expedition for which a campaign badge has been authorized) in any of its programs or activities.

University policy is intended to be consistent with the provisions of applicable State and Federal laws.

Inquiries regarding the University's nondiscrimination policies may be directed to the Affirmative Action/Staff Personnel Services Director, University of California, Agriculture and Natural Resources, 1111 Franklin Street, $6^{\text {th }}$ Floor, Oakland, CA 94607, (510) 987-0096. For information about obtaining this publication, call (800) 994-8849. For downloading information, call (530) 754-3927.

pr-1/09-WJC/RW 